\title{
Preference of red mite Tetranychus ludeni Zacher (Acari: Tetranychidae) to sweet potato genotypes
}

\author{
B. M. C. Castro ${ }^{a *}$, M. A. Soares ${ }^{b}$, V. C. Andrade Júnior ${ }^{c}$, V. C. Santos Júnior ${ }^{\text {, }}$, \\ P. C. R. Fontes ${ }^{a}$, C. F. Wilcken ${ }^{e}$, J. E. Serrão ${ }^{f}$ and J. C. Zanuncio ${ }^{d}$
}

${ }^{a}$ Departamento de Fitotecnia, Universidade Federal de Viçosa - UFV, Av. Peter Henry Rolfs, s/n, Campus Universitário, CEP 36570-900, Viçosa, MG, Brasil

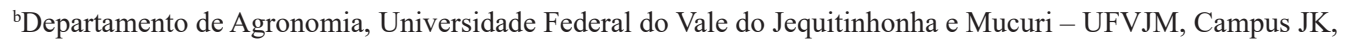
Rodovia MGT 367, Km 583, 5000, Alto da Jacuba, CEP 39100-000, Diamantina, MG, Brasil

'Departamento de Agricultura, Universidade Federal de Lavras - UFLA, Campus Universitário, Caixa Postal 3037, CEP 37200-000, Lavras, MG, Brasil

${ }^{\mathrm{d}}$ Departamento de Entomologia/ Instituto de Biotecnologia Aplicada à Agropecuária (BIOAGRO), Universidade Federal de Viçosa - UFV, Av. Peter Henry Rolfs, s/n, Campus Universitário, CEP 36570-900, Viçosa, MG, Brasil

'Departamento de Proteção Vegetal, Faculdade de Ciências Agronômicas, Universidade Estadual Paulista - UNESP, Caixa-postal 237, CEP 18610-307, Botucatu, SP, Brasil

fDepartamento de Biologia Geral, Universidade Federal de Viçosa - UFV, Av. Peter Henry Rolfs, s/n, Campus Universitário, CEP 36570-900, Viçosa, MG, Brasil

*e-mail: barbaramcastro@hotmail.com

Received: March 06, 2017 - Accepted: October 30, 2017 - Distributed: May 31, 2019

\begin{abstract}
Tetranychus ludeni damages the sweet potato. Pest development can vary between plant genotypes. The objective was to identify the preference of Tetranychus ludeni for Ipomoea batatas genotypes, from the germplasm bank at the Universidade Federal dos Vales do Jequitinhonha e Mucuri (UFVJM). Natural infestations of this mite were observed on 54 sweet potato genotypes in potted, in a greenhouse. Three mite-infested leafs of each genotype were collected and analyzed. The red mite showed different population density rate in genotypes. The BD 29 genotype was found to be highly susceptible, the BD 08, BD 57, BD 17 and Espanhola genotypes were moderately susceptible, and the others forty-nine genotypes showed low susceptibility to the mite.
\end{abstract}

Keywords: antibiosis, antixenosis, Ipomoea batatas, resistance.

\section{Preferência do ácaro vermelho Tetranychus ludeni Zacher (Acari: Tetranychidae) por genótipos de batata-doce}

\section{Resumo}

Tetranychus ludeni danifica plantas de batata-doce. O desenvolvimento de pragas pode variar entre genótipos de plantas. O objetivo foi identificar a preferência de T. ludeni para genótipos de Ipomoea batatas do banco de germoplasma da Universidade Federal dos Vales do Jequitinhonha e Mucuri (UFVJM). Infestações naturais deste ácaro foram observadas em 54 genótipos de batata doce plantados em vasos e mantidos em estufa. Três folhas infestadas por ácaros, de cada genótipo, foram coletadas e analisadas. Tetranychus ludeni mostrou diferentes taxas de crescimento populacional entres os genótipos. O genótipo BD 29 foi altamente suscetível, os BD 08, BD 57, BD 17 e Espanhola foram moderadamente suscetíveis e os outros 49 genótipos mostraram baixa suscetibilidade ao ácaro.

Palavras-chave: antibiose, antixenose, Ipomoea batatas, resistência.

\section{Introduction}

Mites herbivores are common pest in agriculture (Ghazy and Suzuki, 2014; Navia et al., 2009), ornamental plants (Silva et al., 2009) and forests (Pereira et al., 2012; Deus et al., 2012) infesting a wide range of plant hosts (Mendonça et al., 2011) and are among the most important pests across the world. Tetranychus ludeni Zacher
(Acari: Tetranychidae) commonly found in the tropics (Zhang, 2002), occurs worldwide and infests more than 250 plant species (Gotoh et al., 2015), especially eggplant (Solanum melongena) and okra (Abelmoschus esculentus) (Reddy, 2001). This mite has potential to cause severe damage and death to sweet potato plants (Soares et al., 2012). 
Tetranychus ludeni is better adapted to hot weather than T. urticae and has a high potential to become serious pest in other cultures (Gotoh et al., 2015).

Ipomoea batatas (L.) Lam. (Convolvulaceae) is an important crop with social significance (family agriculture) in northeastern Brazil (Albuquerque et al., 2012; Wang et al., 2013) and in the Vale do Jequitinhonha, northeast Minas Gerais State, Brazil (Andrade et al., 2009).

Acaricides are the main control strategy employed to deal with these pests in vegetable crops (Kousik et al., 2007); however, they may prove to be disadvantageous over the long-term (Razmjou et al., 2009) due to pest resistance (Maniania et al., 2008), interfering in the biological control (Moscardini et al., 2014; Castro et al., 2013, 2015) and increasing pest-related problems (Atakan, 2006; Leite et al., 2006). Therefore, intensive acaricide use should be minimized in pest control (Leite et al., 2003).

Pest development varies with the plant genotypes (Hochwender et al., 2005), such as the decreased development of T. urticae on the rose cultivar Virginia than on Emma, Gala and Luna ones (Landeros Flores et al., 2013). The development period was longer and the survival and reproduction lower for T. urticae on the strawberry (Fragaria $x$ ananassa) cultivars than on the Camarosa, Diamond and Seascape ones (Monteiro et al., 2014). Sweet potato genotypes show resistance to pests like Diabrotica spp. (Jackson and Bohac, 2007), Chaetocnema confinis Crotch (Abney and Kennedy, 2011) (Coleoptera: Chrysomelidae), and the root borer, Euscepes postfasciatus (Coleoptera: Curculionidae) (Okada et al., 2014).

The objective was to identify the preference of Tetranychus ludeni for Ipomoea batatas genotypes, from the germplasm bank at the Universidade Federal dos Vales do Jequitinhonha e Mucuri (UFVJM).

\section{Material and Methods}

The sweet potato germplasm bank of the Vegetable Crop Sector of the Universidade Federal dos Vales do Jequitinhonha e Mucuri (UFVJM) has 54 genotypes (BD-29, BD-08, BD-57, BD-17, Espanhola, BD-55, BD-54, BD-13, Tomba Carro 2, BD-24, BD-47, BD-18, BD-07, BD-48, Brazlândia Rosada, Palmas, BD-67, Licuri, Princesa, BD-39, BD-111TO, BD-46, BD-44, BD-42, BD-35, BD-22, BD-02, BD-69, BD-27, BD-25, BD-26, BD-113TO, Brazlândia Roxa, BD-23, BD-43, Tomba Carro 1, BD-12, BD-65, Batata mandioca, BD-70, BD-50, BD-05, BD-38, BD-56, Arruba, BD-53, Cambraia, BD-62, BD-04, BD-03, BD-31TO, Brazlândia Branca, Marmel and BD-33). Natural infestations of mites were observed, in greenhouse, on these genotypes in August 2011 (Soares et al., 2012). Specimens of this mite were sent to Dr. Gilberto José de Moraes of "Escola Superior de Agricultura Luiz de Queiroz" (ESALQ-USP), who identified them as Tetranychus ludeni Zacher (Acari: Tetranychidae).

The sweet potato genotypes were planted in 10-liter pots in a greenhouse and watered daily. Three sweet potato branches were transplanted per pot with soil, fertilized and limed as recommended for the crop. The experimental design was completely randomized with 54 treatments (genotypes), three replications and three plants per pot to represent each experimental unit.

A natural T. ludeni outbreak was observed 90 days post transplantation of the sweet potato branches. Three infested leafs were collected per genotype. They were taken for analysis to the laboratory of Entomology (UFVJM). An area of $3.8 \mathrm{~cm}^{2}$ covering the midrib of the abaxial surface of leafs (the most frequent point of mite occurrence), was photographed using a camera coupled with an optical microscope. The T. ludeni adults were counted on the leaf area with computer assistance.

Data were subjected to the analysis of variance and the means were grouped using the Scott-Knott test at $5 \%$ probability, employing the statistical analysis program SAEG.

\section{Results and Discussion}

Tetranychus ludeni showed lower population density rate on different $I$. batatas genotypes $(\mathrm{F}=3.55 ; \mathrm{df}=53,108 ; \mathrm{P}<0.0001)$. The genotypes were categorized under three groups: high, moderate or low susceptibility to this mite, indicating the resistance mechanisms in these plants.

The BD 29 genotype $(72.33 \pm 29.19)$ was the most infested and was therefore classified as highly susceptible (Table 1). Density, distribution, and damage by pests vary with genotype (Hochwender et al., 2005), being plant resistance correlated with their genetic characteristics (Leimu and Koricheva, 2006). Plant preferences can be based on chemical (Kos et al., 2014) and/or morphological mechanisms such as leaf toughness, trichomes, density, stomata size, and epicuticular wax content (Nair et al., 2012). The research and selection of resistant genotypes may contribute to integrated pest management (IPM) aimed at safely, economically, and ecologically methods to eliminate pests (Ehler, 2006), in a more sustainable manner over the long term (Soares et al., 2007; Soares et al., 2009).

The BD 08, BD 57, BD 17 and the Espanhola were moderately susceptible and the others showed low susceptibility to T. ludeni. The development of the mites may vary between the genotypes of the same species (Modarres Najafabadi et al., 2014) as reported for Amphitetranychus viennensis Zacher and Tetranychus urticae Koch (Acari: Tetranychidae) on apples (Kasap, 2003) and T. urticae on strawberry (Wold and Hutchison, 2003), cucumber (Park and Lee, 2007) and tomato (Keskin and Kumral, 2015). The total height, number of leafs, flowers and fruits and fruit weight were found to be lower on the eggplant (Solanum melongena L. Solanaceae) cultivar Panruti than on the other varieties of this plant (Reddy and Baskaran, 2006). The resistance of the Phaseolus vulgaris L. cultivars to T. urticae also varied. The Akhtar and GS11867 varieties are susceptible, while the KS41128 and Naz are resistant (Tahmasebi et al., 2014). Resistant cultivars can reduce pest population density and is a 
Table 1. Number of individuals of the red mite Tetranychus ludeni Zacher (Acari: Tetranychidae) (average \pm standard deviation) on leafs of sweet potato genotypes (Ipomoea batatas).

\begin{tabular}{|c|c|c|c|}
\hline \multicolumn{4}{|c|}{ Genotype with high susceptibility } \\
\hline BD -29 & $72.33 \pm 29.19^{\mathrm{A}}$ & & \\
\hline \multicolumn{4}{|c|}{ Genotypes with moderate susceptibility } \\
\hline BD- 08 & $51.00 \pm 16.82^{\mathrm{B}}$ & BD-17 & $37.67 \pm 32.62^{\mathrm{B}}$ \\
\hline $\mathrm{BD}-57$ & $42.67 \pm 27.06^{\mathrm{B}}$ & Espanhola & $36.33 \pm 14.84^{\mathrm{B}}$ \\
\hline \multicolumn{4}{|c|}{ Genotypes with low susceptibility } \\
\hline BD-55 & $26.33 \pm 15.34^{\mathrm{C}}$ & BD-26 & $11.67 \pm 7.09^{\mathrm{C}}$ \\
\hline BD-54 & $26.33 \pm 4.72^{\mathrm{C}}$ & BD-113TO & $11.33 \pm 6.65^{\mathrm{c}}$ \\
\hline BD-13 & $26.00 \pm 5.19^{\mathrm{C}}$ & Brazlândia Roxa & $11.00 \pm 10.14^{\mathrm{C}}$ \\
\hline Tomba Carro 2 & $25.00 \pm 13.31^{\mathrm{C}}$ & $\mathrm{BD}-23$ & $10.67 \pm 4.72^{\mathrm{C}}$ \\
\hline BD-24 & $23.00 \pm 10.58^{\mathrm{C}}$ & BD-43 & $10.33 \pm 4.50^{\mathrm{C}}$ \\
\hline BD-47 & $21.00 \pm 19.97^{\mathrm{C}}$ & Tomba Carro 1 & $9.33 \pm 2.51^{\mathrm{C}}$ \\
\hline BD-18 & $21.00 \pm 6.55^{\mathrm{C}}$ & BD-12 & $8.67 \pm 5.69^{\mathrm{C}}$ \\
\hline BD-07 & $20.67 \pm 2.30^{\mathrm{C}}$ & BD-65 & $8.67 \pm 1.52^{\mathrm{C}}$ \\
\hline BD-48 & $19.00 \pm 13.52^{\mathrm{C}}$ & Batata Mandioca & $8.00 \pm 7.81^{\mathrm{C}}$ \\
\hline Brazlândia Rosada & $18.67 \pm 10.59^{\mathrm{C}}$ & BD-70 & $7.67 \pm 4.70^{\mathrm{C}}$ \\
\hline Palmas & $18.33 \pm 14.22^{\mathrm{C}}$ & BD-50 & $7.00 \pm 5.56^{\mathrm{C}}$ \\
\hline BD-67 & $18.00 \pm 15.62^{\mathrm{C}}$ & BD-05 & $6.67 \pm 2.08^{\mathrm{C}}$ \\
\hline Licuri & $18.00 \pm 10.06^{\mathrm{C}}$ & BD-38 & $6.67 \pm 4.04^{\mathrm{C}}$ \\
\hline Princesa & $18.00 \pm 11.13^{\mathrm{C}}$ & BD-56 & $5.67 \pm 1.52^{\mathrm{C}}$ \\
\hline BD-39 & $17.67 \pm 4.61^{\mathrm{C}}$ & Arruba & $5.67 \pm 1.52^{\mathrm{C}}$ \\
\hline BD-111TO & $17.67 \pm 9.07^{\mathrm{C}}$ & BD-53 & $4.33 \pm 1.52^{\mathrm{C}}$ \\
\hline BD-46 & $17.67 \pm 13.20^{\mathrm{C}}$ & Cambraia & $4.33 \pm 1.15^{\mathrm{C}}$ \\
\hline BD-44 & $17.00 \pm 4.00^{\mathrm{C}}$ & BD-62 & $4.00 \pm 1.73^{\mathrm{C}}$ \\
\hline BD-42 & $16.67 \pm 8.32^{\mathrm{C}}$ & BD-04 & $3.67 \pm 2.51^{\mathrm{C}}$ \\
\hline BD-35 & $15.67 \pm 1.01^{\mathrm{C}}$ & BD-03 & $3.00 \pm 1.00^{\mathrm{C}}$ \\
\hline BD-22 & $14.00 \pm 6.00^{\mathrm{C}}$ & BD-31TO & $2.33 \pm 0.57^{\mathrm{C}}$ \\
\hline BD-02 & $13.00 \pm 2.16^{\mathrm{C}}$ & Brazlândia Branca & $1.67 \pm 1.52^{\mathrm{C}}$ \\
\hline BD-69 & $12.67 \pm 8.68^{\mathrm{C}}$ & Marmel & $1.67 \pm 0.57^{\mathrm{C}}$ \\
\hline BD-27 & $12.67 \pm 7.23^{\mathrm{C}}$ & BD-33 & $1.00 \pm 1.00^{\mathrm{C}}$ \\
\hline BD-25 & $12.00 \pm 1.35^{\mathrm{C}}$ & & \\
\hline
\end{tabular}

Means followed by the same letter were grouped using the Scott-Knott test at $5 \%$ probability.

method compatible with other management tactics, such as biological control (Castro et al., 2014), an important aspect of IPM (Razmjou et al., 2009; Landeros Flores et al., 2013) and furthermore minimizes the application of chemicals (Zehnder et al., 2007) and consequently, the production costs.

\section{Conclusions}

The population density rate of T. ludeni was different in each of the sweet potato genotypes. The BD 29 was found to be highly susceptible, the BD 08, BD 57, BD 17 and Espanhola genotypes were moderately susceptible, while the others showed low susceptibility to T. ludeni.

\section{Acknowledgements}

To Dr. Gilberto José de Moraes (ESALQ-USP) for the identification of the mite. To Coordenação de Aperfeiçoamento de Pessoal de Nível Superior (CAPES),
Conselho Nacional de Desenvolvimento Científico e Tecnológico (CNPq), Fundação de Amparo a Pesquisa do Estado de Minas Gerais (FAPEMIG) and Empresa Brasileira de Pesquisa Agropecuária (EMBRAPA) for financial support. Global Edico Services corrected and rewrote the English of this manuscript.

\section{References}

ABNEY, M.R. and KENNEDY, G.G., 2011. Relative susceptibility of two sweet potato varieties to storage root damage by sweet potato flea beetle (Coleoptera: Chrysomelidae) and wireworm (Coleoptera: Elateridae). Journal of Economic Entomology, vol. 104, no. 1, pp. 143-148. http://dx.doi.org/10.1603/EC10196. PMid:21404851.

ALBUQUERQUE, L.C., INOUE-NAGATA, A.K., PINHEIRO, B., RESENDE, R.O., MORIONES, E. and NAVAS-CASTILLO, J., 2012. Genetic diversity and recombination analysis of sweepoviruses from Brazil. Virology Journal, vol. 9, no. 1, pp. 241-254. http:// dx.doi.org/10.1186/1743-422X-9-241. PMid:23082767. 
ANDRADE, V.C. Jr., VIANA, D.J.S., FERNANDES, J.S.C., FIGUEIREDO, J.A., NUNES, U.R. and NEIVA, I.P., 2009. Selection of sweet potato clones for the region Alto Vale do Jequitinhonha. Horticultura Brasileira, vol. 27, no. 3, pp. 389-393. http://dx.doi. org/10.1590/S0102-05362009000300024.

ATAKAN, E., 2006. Associations between Frankliniella spp. and Orius niger populations in cotton. Phytoparasitica, vol. 34, no. 3 , pp. 221-234. http://dx.doi.org/10.1007/BF02980949.

CASTRO, A.A., CORRÊA, A.S., LEGASPI, J.C., GUEDES, R.N.C., SERRÃO, J.E. and ZANUNCIO, J.C., 2013. Survival and behavior of the insecticide-exposed predators Podisus nigrispinus and Supputius cincticeps (Heteroptera: Pentatomidae). Chemosphere, vol. 93, no. 6, pp. 1043-1050. http://dx.doi. org/10.1016/j.chemosphere.2013.05.075. PMid:23880241.

CASTRO, A.A., PODEROSO, J.C.M., RIBEIRO, R.C., LEGASPI, J.C., SERRÃO, J.E. and ZANUNCIO, J.C., 2015. Demographic parameters of the insecticide-exposed predator Podisus nigrispinus: implications for IPM. BioControl, vol. 60, no. 2, pp. 231-239. http://dx.doi.org/10.1007/s10526-014-9639-y.

CASTRO, B.M., SOARES, M.A., ANDRADE JÚNIOR, V.C., FADINI, M.A., FERREIRA, J.A. and MORAES, G.J., 2014. The predatory mite Phytoseiulus macropilis (Acari: Phytoseiidae) occurring on sweet potato (Ipomoea batatas) plants in Diamantina, Minas Gerais State, Brazil. Brazilian Journal of Biology $=$ Revista Brasileira de Biologia, vol. 74, no. 3, pp. 685-686. http://dx.doi. org/10.1590/bjb.2014.0078. PMid:25296218.

DEUS, E.G., SOUZA, M.S.M., MINEIRO, J.L.C., ADAIME, R. and SANTOS, R.S., 2012. Mites (Arachnida: Acari) collected on rubber trees Hevea brasiliensis (Willd. ex A.Juss.) Müll.Arg. in Santana, Amapá state, Brazil. Brazilian Journal of Biology = Revista Brasileira de Biologia, vol. 72, no. 4, pp. 915-918. http:// dx.doi.org/10.1590/S1519-69842012000500019. PMid:23295522.

EHLER, L.E., 2006. Integrated pest management (IPM): definition, historical development and implementation, and the other IPM. Pest Management Science, vol. 62, no. 9, pp. 787-789. http:// dx.doi.org/10.1002/ps.1247. PMid:16786545.

GHAZY, N.A. and SUZUKI, T., 2014. Desiccation tolerance in diapausing spider mites Tetranychus urticae and T. kanzawai (Acari: Tetranychidae). Experimental \& Applied Acarology, vol. 63, no. 1, pp. 49-55. http://dx.doi.org/10.1007/s10493-013-97600. PMid:24306933.

GOTOH, T., MORIYA, D. and NACHMAN, G., 2015. Development and reproduction of five Tetranychus species (Acari: Tetranychidae): Do they all have the potential to become major pests? Experimental \& Applied Acarology, vol. 66, no. 4, pp. 453-479. http://dx.doi. org/10.1007/s10493-015-9919-y. PMid:26014647.

HOCHWENDER, C.G., JANSON, E.M., CHA, D.H. and FRITZ, R.S., 2005. Community structure of insect herbivores in a hybrid system: examining the effects of browsing damage and plant genetic variation. Ecological Entomology, vol. 30, no. 2, pp. 170-175. http://dx.doi.org/10.1111/j.0307-6946.2005.00685.x.

JACKSON, D.M. and BOHAC, J.R., 2007. Resistance of sweet potato genotypes to adult Diabrotica beetles. Journal of Economic Entomology, vol. 100, no. 2, pp. 566-572. http:// dx.doi.org/10.1603/0022-0493(2007)100[566:ROSGTA]2.0. CO;2. PMid: 17461084

KASAP, I., 2003. Life history of hawthorn spider mite Amphitetranychus viennensis (Acarina: Tetranychidae) on various apple cultivars and at different temperatures. Experimental \&
Applied Acarology, vol. 31, no. 1-2, pp. 79-91. http://dx.doi. org/10.1023/B:APPA.0000005141.45970.f7. PMid:14756403.

KESKIN, N. and KUMRAL, N.A., 2015. Screening tomato varietal resistance against the two-spotted spider mite [Tetranychus urticae (Koch)]. International Journal of Acarology, vol. 41, no. 4, pp. 300-309. http://dx.doi.org/10.1080/01647954.2015.1028440.

KOS, S.P., KLINKHAMER, P.G.L. and LEISS, K.A., 2014. Cross-resistance of chrysanthemum to western flower thrips, celery leafminer, and two-spotted spider mite. Entomologia Experimentalis et Applicata, vol. 151, no. 3, pp. 198-208. http:// dx.doi.org/10.1111/eea.12185.

KOUSIK, C.S., SHEPARD, B.M., HASSELL, R., LEVI, A. and SIMMONS, A.M., 2007. Potential sources of resistance to broad mites Polyphagotarsonemus latus in watermelon germplasm. HortScience, vol. 42, no. 7, pp. 1539-1544.

LANDEROS FLORES, J., CHÁVEZ, E.C., AGUIRRE URIBE, L.A., CANALES, R.F. and OCHOA FUENTES, Y.M., 2013. Demographic parameters of Tetranychus urticae (Acari: Tetranychidae) on four Rosa sp. cultivars. The Florida Entomologist, vol. 96, no. 4, pp. 1508-1512. http://dx.doi.org/10.1653/024.096.0432.

LEIMU, R. and KORICHEVA, J., 2006. A meta-analysis of genetic correlations between plant resistances to multiple enemies. American Naturalist, vol. 168, no. 1, pp. E15-E37. http://dx.doi. org/10.1086/505766. PMid:16874611.

LEITE, G.L.D., PICANÇO, M., ZANUNCIO, J.C. and CARVALHO, C.E., 2006. Factors affecting herbivory of Thrips palmi (Thysanoptera: Thripidae) and Aphis gossypii (Homoptera: Aphididae) on the eggplant (Solanum melongena). Brazilian Archives of Biology and Technology, vol. 49, no. 3, pp. 361-369. http://dx.doi.org/10.1590/S1516-89132006000400002.

LEITE, G.L.D., PICANÇO, M., ZANUNCIO, J.C. and MARQUINI, F., 2003. Factors affecting mite herbivory on egg plants in Brazil. Experimental \& Applied Acarology, vol. 31, no. 3-4, pp. 243252. http://dx.doi.org/10.1023/B:APPA.0000010379.05878.2c. PMid:14974689.

MANIANIA, N.K., BUGEME, D.M., WEKESA, V.W., DELALIBERA JÚNIOR, J.R.I. and KNAPP, M., 2008. Role of entomopathogenic fungi in the control of Tetranychus evansi and Tetranychus urticae (Acari: Tetranychidae); pests of horticultural crops. Experimental \& Applied Acarology, vol. 46, no. 1-4, pp. 259-274. http://dx.doi. org/10.1007/s10493-008-9180-8. PMid:18685956.

MENDONÇA, R.S., NAVIA, D., DINIZ, I.R. and FLECHTMANN, C.H.W., 2011. South American spider mites: new hosts and localities. Journal of Insect Science, vol. 11, no. 1, pp.1-18. https://dx.doi.org/10.1673/031.011.12101

MODARRES NAJAFABADI, S.S., SHOUSHTARI, R.V., ZAMANI, A.A., ARBABI, M. and FARAZMAND, H., 2014. Life parameters of Tetranychus urticae (Acari: Tetranychidae) on six common bean cultivars. Journal of Economic Entomology, vol. 107, no. 2, pp. 614-622. http://dx.doi.org/10.1603/EC11205. PMid:24772541.

MONTEIRO, L.B., KUHN, T.M.A., MOGOR, A.F. and SILVA, E.D.B., 2014. Biology of the two-spotted spider mite on strawberry plants. Neotropical Entomology, vol. 43, no. 2, pp. 183-188. https://dx.doi.org/10.1007/s13744-013-0184-7.

MOSCARDINI, V.F., GONTIJO, P.C., MICHAUD, J.P. and CARVALHO, G.A., 2014. Sublethal effects of chlorantraniliprole and thiamethoxam seed treatments when Lysiphlebus testaceipes 
feed on sunflower extrafloral néctar. BioControl, vol. 59, no. 5, pp. 503-511. http://dx.doi.org/10.1007/s10526-014-9588-5.

NAIR, S., BRAMAN, K. and KNAUFT, D.A., 2012. Resistance mechanisms in Pieris taxa (Ericaceae) to Stephanitis takeyai (Hemiptera: Tingidae). Environmental Entomology, vol. 41, no. 5, pp. 1153-1162. http://dx.doi.org/10.1603/EN11323. PMid:23068172.

NAVIA, D., MORAES, G.J. and QUERINO, R.B., 2009. Geographic pattern of morphological variation of the coconut mite, Aceria guerreronis Keifer (Acari: Eriophyidae), using multivariate morphometry. Brazilian Journal of Biology = Revista Brasileira de Biologia, vol. 69, no. 3, pp. 773-783. http://dx.doi.org/10.1590/ S1519-69842009000400004. PMid:19802436.

OKADA, Y., YASUDA, K., SAKAI, T. and ICHINOSE, K., 2014. Sweet potato resistance to Euscepes postfasciatus (Coleoptera: Curculionidae): larval performance adversely effected by adult's preference to tuber for food and oviposition. Journal of Economic Entomology, vol. 107, no. 4, pp. 1662-1673. http://dx.doi. org/10.1603/EC13377. PMid:25195460.

PARK, Y.L. and LEE, J.H., 2007. Seasonal dynamics of economic injury levels for Tetranychus urticae Koch (Acari: Tetranychidae) on Cucumis sativus L. Journal of Applied Entomology, vol. 131, no. 8, pp. 588-592. http://dx.doi.org/10.1111/j.1439-0418.2007.01217.x.

PEREIRA, A.I.A., FADINI, M.A.M., PIKART, T.G., ZANUNCIO, J.C. and SERRÃO, J.E., 2012. New hosts and parasitism notes for the mite Leptus (Acari: Erythraeidae) in fragments of the Atlantic Forest; Brazil. Brazilian Journal of Biology $=$ Revista Brasileira de Biologia, vol. 72, no. 3, pp. 611-616. http://dx.doi.org/10.1590/ S1519-69842012000300026. PMid:22990834.

RAZMJOU, J., TAVAKKOLI, H. and FALLAHI, A., 2009. Effect of soybean cultivar on life history parameters of Tetranychus urticae Koch (Acari: Tetranychidae). Journal of Pest Science, vol. 82, no. 1, pp. 89-94. http://dx.doi.org/10.1007/s10340-008-0227-8.

REDDY, G.V.P. and BASKARAN, P., 2006. Damage potential of the spider mite Tetranychus ludeni (Acari: Tetranychidae) on four varieties of eggplant. International Journal of Tropical Insect Science, vol. 26, no. 1, pp. 48-56. http://dx.doi.org/10.1079/ IJT2006102.

REDDY, G.V.P., 2001. Comparative effectiveness of an integrated pest management system and other control tactics for managing the spider mite Tetranychus ludeni (Acari: Tetranychidae) on eggplant. Experimental \& Applied Acarology, vol. 25, no. 12, pp. 985-992. http://dx.doi.org/10.1023/A:1020661215827. PMid:12465852.

SILVA, E.A., REIS, P.R., CARVALHO, T.M.B. and ALTOÉ, B.F., 2009. Tetranychus urticae (Acari: Tetranychidae) on Gerbera jamesonii Bolus and Hook (Asteraceae). Brazilian Journal of
Biology $=$ Revista Brasileira de Biologia, vol. 69, no. 4, pp. 1121-1125. http://dx.doi.org/10.1590/S1519-69842009000500016. PMid:19967183.

SOARES, M.A., CASTRO, B.M.C., ANDRADE-JÚNIOR, V.C., ASSIS-JÚNIOR, S.L. and PIRES, E.M., 2012. Attack of two new spider mites on sweet potato (Ipomoea batatas) in Diamantina; Minas Gerais State; Brazil. Brazilian Journal of Biology = Revista Brasileira de Biologia, vol. 72, no. 4, pp. 971. http:// dx.doi.org/10.1590/S1519-69842012000500029. PMid:23295532.

SOARES, M.A., LEITE, G.L.D., ZANUNCIO, J.C., ROCHA, S.L., SÁ, V.G.M. and SERRÃO, J.E., 2007. Flight capacity, parasitism and emergence of five Trichogramma (Hymenoptera: Trichogrammatidae) species from forest areas in Brazil. Phytoparasitica, vol. 35, no. 3, pp. 314-318. http://dx.doi. org/10.1007/BF02981165.

SOARES, M.A.,ZANUNCIO, J.C., LEITE, G.L.D., WERMELINGER, E.D. and SERRÃO, J.E., 2009. Does Thyrinteina arnobia (Lepidoptera: Geometridae) use different defense behaviours against predators? Journal of Plant Diseases and Protection, vol. 116, no. 1, pp. 30-33. http://dx.doi.org/10.1007/BF03356283.

TAHMASEBI, Z., MOHAMMADI, H., ARIMURA, G., MUROI, A. and KANT, M.R., 2014. Herbivore-induced indirect defense across bean cultivars is independent of their degree of direct resistance. Experimental \& Applied Acarology, vol. 63, no. 2, pp. 217-239. http://dx.doi.org/10.1007/s10493-014-9770-6. PMid:24531863.

WANG, M., SHI, Y., XIA, X., LI, D. and CHEN, Q., 2013. Lifecycle energy efficiency and environmental impacts of bioethanol production from sweet potato. Bioresource Technology, vol. 133, no. 2, pp. 285-292. http://dx.doi.org/10.1016/j.biortech.2013.01.067. PMid:23434804

WOLD, S.J. and HUTCHISON, W.D., 2003. Varietal resistance to Tetranychus urticae Koch (Acari: Tetranychidae) in Minnesota strawberries and control with bifenthrin. Journal of Entomological Science, vol. 38, no. 4, pp. 692-695. http://dx.doi.org/10.18474/07498004-38.4.692

ZEHNDER, G., GURR, G.M., KUHNE, S., WADE, M.R., WRATTEN, S.D. and WYSS, E., 2007. Arthropod pest management in organic crops. Annual Review of Entomology, vol. 52, no. 1, pp. 57-80. http://dx.doi.org/10.1146/annurev.ento.52.110405.091337. PMid:16846384.

ZHANG, Z.Q., 2002. Taxonomy of Tetranychus ludeni (Acari: Tetranychidae) in New Zealand and its ecology on Sechium edule. New Zealand Entomologist, vol. 25, no. 1, pp. 17-34. http://dx.doi. org/10.1080/00779962.2002.9722091. 